\title{
Fruit Nutrients of Five Species of Wild Raspberries (Rubus spp.) from Indonesian Mountain's Forests
}

\author{
Muhammad Imam Surya ${ }^{1 *}$, Siti Suhartati ${ }^{2}$, Lily Ismaini ${ }^{1}$, Yuyun Lusini ${ }^{2}$, Destri ${ }^{1}$, Dian Anggraeni ${ }^{2}$, Suluh Normasiwi ${ }^{1}$, Nurul \\ Asni $^{2}$, Mirwan Abu Bakar Sidiq ${ }^{2}$
}

${ }^{1}$ Cibodas Botanical Garden, Indonesian Institute of Sciences, Cianjur, Indonesia

${ }^{2}$ Academy of Analytical Chemistry Caraka Nusantara, Depok, Indonesia

\begin{abstract}
Rubus spp. (wild raspberries) is one of genera belongs to Rosaceae, also distributed in the mountain forest of Indonesia. It has a high potency to be cultivated plant. Although, some of the potential of Rubus has already known, information of about fruit nutrients of species that distribute in the mountain forest of Indonesia are not known yet. This study was aimed to determine the fruit nutrients of five species of wild raspberries that was collected in Cibodas Botanical Garden. The results of our experiments demonstrate that the fruits nutrients contents varied among five species of wild raspberries from Indonesian mountain's forests. Rubus fraxinifolius has the highest content of sugar (5.05 g sugar per $100 \mathrm{~g}$ fruits) compared to Rubus rosifolius, Rubus chrysophyllus, Rubus lineatus and raspberry. During the ripening and ripe period, there were a different value of vitamin $\mathrm{C}$ and iron contents. The highest vitamin $C$ of $R$. fraxinifolius $(83.65 \mathrm{mg} / 100$ gram) on the ripening fruit stage II. On the other hand, the highest vitamin $C$ of $R$. rosifolius $(54.30 \mathrm{mg} / 100 \mathrm{gram})$ found on the stage of ripe fruit.
\end{abstract}

Keywords: Fruit nutrient, Indonesia, Rubus, wild raspberries

\section{INTRODUCTION}

The wild relative of fruit crops produces a range of essential heads such as food, fuel, timber, etc. The wild relative crops are the wild ancestors of crop plant and other species closely related to crops [1]. Rubus is one of the genera belongs to Rosaceae, also distributed in the mountain forest of Indonesia. It has a highly potential to be developed as crops cultivated plant. The genus Rubus, one of the largest plant genus containing over 740 species, is native to six continents and can grow in several locations [2, 3]. Furthermore, there was reported that 46 species of Rubus has found in Malesia Region, and 25 species distributed in Indonesia [4, 5, 6]. Many of them have great potency to use in crop improvement program and domestication. Currently, Cibodas Botanical Gardens as an institute of ex situ conservation has been collected eleven Rubus species (Rubus alpestris, Rubus alcefolius, Rubus chrysophyllus, Rubus elongatus,

*Corresponding author:

Muhammad Imam Surya

Cibodas Botanical Garden, Indonesian Institute of Sciences

Jalan Kebun Raya Cibodas, Po Box 19 Sindanglaya, Cianjur,

Indonesia 43253

E mail: muhammad.imam.surya@lipi.go.id
Rubus ellipticus, Rubus fraxinifolius, Rubus glomeratus, Rubus lineatus, Rubus moluccanus, Rubus rosifolius, Rubus pyrifolius, dan Rubus sp.), some of them were collected from mountain of Indonesia, and also five out of eleven (Figure 1) were grow well [7, 8, 9].

Rubus is economically and ecologically important; as fruits crops, ornamental, invasive weeds, and in early forest succession $[10,11,12]$. In Cianjur-West Java, people already knew that $R$. fraxinifolius, called arben, is edible and has a potential for commercial fruit. In several countries such as United States of America, Russia, United Kingdom, Australia, China, Japan, some species of wild crop relative of Rubus has been domesticated and used as a fresh fruit and derivative products $[13,14]$. In the other hand, the potential health benefits of berry consumption are now the subject of considerable public investment by various bodies including industry and governments. Moreover, $R$. idaeus is a species that com-

\section{How to cite:}

Surya MI, Suhartati S, Ismaini L et al. (2018) Fruit Nutrients of Five Species of Wild Raspberries (Rubus spp.) from Indonesian Mountain's Forests. J. Trop. Life. Science 8 (1): $75-80$. 


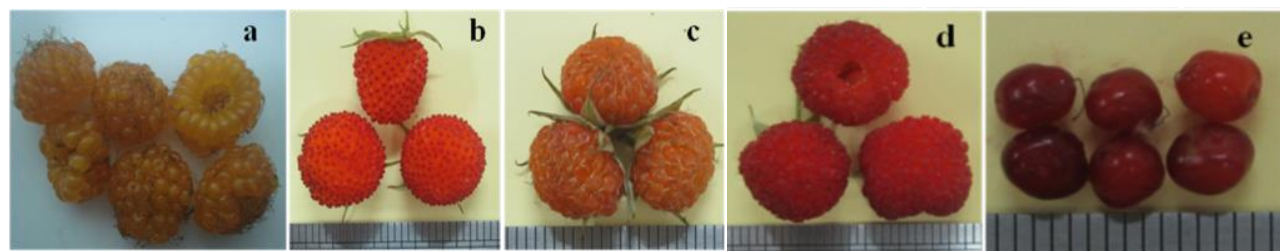

Figure 1. Five species of wild raspberries [ (a) $R$. chrysophyllus; (b) $R$. fraxinifolius; (c) $R$. lineatus; (d) R. rosifolius; and (e) $R$. pyrifolius]

Table 1. Five species of Rubus spp.

\begin{tabular}{|c|c|c|}
\hline Species & $\begin{array}{l}\text { Time of } \\
\text { Collection }\end{array}$ & Sources \\
\hline Rubus fraxinifolius & - & Garden origin, Cibodas Botanical Garden, Indonesia \\
\hline Rubus rosifolius & 2013 & $\begin{array}{l}\text { Mountain forest Karundeng-Lumut Plateau Bulang, Kab. Tojo Una-una- } \\
\text { Sulawesi Tengah, Indonesia }\end{array}$ \\
\hline Rubus pyrifolius & 1992 & National Park of Mount. Gede Pangrango-West Java, Indonesia \\
\hline Rubus chrysophyllus & 2011 & Mount. Singgalang-West Sumatera, Indonesia \\
\hline Rubus lineatus & 2007 & National Park of Mount. Ciremai-West Java, Indonesia \\
\hline
\end{tabular}

monly develop as commercial raspberry. Kaume et al. [15] and Talcott [16] reported that blackberry chemical composition varies on the basis of variety, growing conditions, stage of ripeness, and harvest and storage conditions. In addition to valuable polyphenolic compounds, blackberries contain carbohydrates and several essential vitamins and minerals. In the other hand, Rubus also has potential as a medicinal plant. Van Valkenburg and Bunyapraphatsara [17] reported that some of Rubus spp. could be used as a medicine for dysentery and diarrhea.

Although some of the potential of Rubus has already known, however information about fruit nutrients of species that distributed in the mountain forest of Indonesia is still unrevealed. The aim of this study is to find out the nutrients content of five species of Rubus spp. that was collected in Cibodas Botanical Garden.

\section{MATERIALS AND METHODS}

\section{Fruit production and harvesting}

The fruit production was carried out in Cibodas Botanical Garden, Cianjur, West Java, Indonesia. Five species of Rubus spp. (Table 1) collected from Cibodas Botanical Garden was used as samples. A hundred gram of mature fruits is harvested from each species. Afterwards, each sample was stored in the bottle containing $50 \mathrm{~g} / \mathrm{L}$ of metaphosphoric. Furthermore, vitamin C, and iron/Fe were analyzed in three stages of fruit maturity i.e. ripening fruit stage $\mathrm{I}$, ripening fruit stage II and ripe fruit.

\section{Nutrients analysis}

The nutrient analysis was carried out in the chemi- cal laboratory of the Academy of Chemical Analysis Caraka Nusantara. The analysis of the fruit included the total of carbohydrate sugars, crude fiber, vitamin C, and the calories. Methods of the analysis were as described in The Chemical of Foods [18].

The analysis of a total of carbohydrate and sugars were based on the reducing activity of glucose in reducing the $\mathrm{Cu}^{2+}$ ion becoming the $\mathrm{Cu}^{1+}$ ion in Fehling solution which consists of copper sulfate, sodium hydroxide, and sodium potassium citrate. The excess of $\mathrm{Cu}^{2+}$ was determined by the iodometric method. The results of determination then were calculated by the factor for the total of carbohydrate and the sugars content respectively.

The crude fiber is the organic residue which remains after the material has been treated with light petroleum, boiling dilute sulphuric acid, boiling dilute sodium hydroxide solution, dilute hydrochloric acid, alcohol, and ether. The crude fiber consists largely of cellulose together with a little lignin.

The vitamin $\mathrm{C}$ content of fruits was analyzed by macerating the sample with the stabilizing agent of $5 \%$ metaphosphoric acid and titrating the filtered extract with 2,6 dichlorophenolindophenol. Firstly, to standarize the indophenol solution by dissolving $0.05 \mathrm{~g} 2.6 \mathrm{di}-$ chlorophenolindophenol in water, diluted to $100 \mathrm{~mL}$ and filtered. Dissolved the pure ascorbic acid exactly $0.05 \mathrm{~g}$ in $60 \mathrm{~mL}$ of $20 \%$ metaphosphoric acid and dilute with water exactly $250 \mathrm{~mL}$. Then pipette $10 \mathrm{~mL}$ of the solution into a small flask and titrate with the indo-phenol solution until a faint pink color persists for $15 \mathrm{sec}-$ onds. Express the concentration as $\mathrm{mg}$ ascorbic acid 
equivalent to $1 \mathrm{mg}$ of the indophenol solution. Fifty grams of the sample of fruit in metaphosphoric solution was blended and then filtered. Pipette $10 \mathrm{~mL}$ of the filtrate into a small flask and titrate with the indophenol solution until a faint pink color persists for 15 seconds. Calculate the vitamin $\mathrm{C}$ content in the sample as $\mathrm{mg}$ per $100 \mathrm{~g}$. The calories content obtained the conversion of the sugar by factor $4.0 \mathrm{kcal}$ per gram.

\section{RESULTS AND DISCUSSION}

The results of nutrient analysis of five species of wild raspberries were shown in Table 2. Carbohydrates are the most abundant constituents in fruits, representing $50 \%$ to $80 \%$ of the total dry weight. The contents of carbohydrate total of the fruits varied among species of Rubus; the contents were between $6.84 \mathrm{~g}$ to $11.48 \mathrm{~g}$. The highest were for the $R$. fraxinifolius and $R$. chrysophyllus, and lowest was $R$. pyrifolius. However, there is similarity content between the $R$. fraxinifolius and $R$. chrysophyllus, and between $R$. rosifolius and $R$. lineatus. Compare with Raspberry from USDA data, five species of wild Rubus had a lower value of total carbohydrate. Rubus are a low energy fruit comprised primarily of natural carbohydrate and dietary fiber, with the main sugar form being fructose and Probst [19] reported that carbohydrate nutrients of raspberry from Australian and New Zealand between 4.90 to 7.50 g per 100 g. Moreover, the results show that sugar content of $R$. fraxinifolius was higher than the USDA data of raspberry and the others species of wild Rubus (Table 2). The type of fruits is affecting the variation of sugar content. Fructose are present on all fruit juices, but vary in their amount of sucrose, glucose and sorbitol [20].

One of the most abundant sugars in fruit juices is fructose. Fructose, also known as fruit sugar, is simple monosaccharide absorbed directly into the bloodstream during digestion. Some people believe fructose is healthier than sucrose because it is found naturally in fruit. However, it can be equally harmful [21]. The calorie of the fruits depended on the content of carbohydra- te total. As shown in Table 2, that if carbohydrate content of Rubus were high, its followed by the highest content of calories.

Crude fiber is the residue of plant food left after extraction by dilute acid followed by dilute alkali [22]. The results of crude fiber content of five species wild Rubus (Table 2 ) varied from was $3.36 \mathrm{mg}$ ( $R$. pyrifolius) to 8.43 $\mathrm{mg}$ ( $R$. chrysophyllus). Ahmad et al. [23] also reported that fiber content of some Rubus varied from $1.66 \%$ ( $R$. ulmifolius) to 5.90 ( $R$. niveus). Although in general our results were higher than Ahmad et al. [23], but only $R$. rosifolius $(7.10 \mathrm{mg}$ ) and $R$. chrysophyllus $(8.43 \mathrm{mg}$ ) had higher crude fiber than raspberry.

Vitamin $\mathrm{C}$ is one of the most potential antioxidants vitamins. Generally, fruits are the best sources of ascorbic acid. Vitamin $\mathrm{C}$ analysis was done on two species of Rubus i.e. $R$. fraxinifolius and $R$. rosifolius. It due to the limitation of fruit production from others species are very limited. In our experiment on $R$. rosifolius and $R$. fraxinifolius, we divided into three level of fruits i.e. ripening fruit stage I, ripening fruit stage II and ripe fruit. Ripening fruits stage I is characterized by dull color, the texture was hard and less juicy, fruit stick to the receptacle. In ripening stage II, the fruit color is redder but not bright and stick to the receptacle. Ripe fruits are bright red or orange, tender and juicy, easy to remove from receptacle. Moreover, the results show that the vitamin $\mathrm{C}$ of $R$. fraxinifolius is higher than $R$. rosifolius (Figure 2). In $R$. fraxinifolius, the highest content of vitamin $C$ was shown on ripening fruit stage II $(83.65$ $\mathrm{mg} / 100$ gram $)$ and followed by ripe fruit $(82.97 \mathrm{mg} / 100$ $\mathrm{g}$ ) and ripening fruit stage $\mathrm{I}(54.62 \mathrm{mg} / 100 \mathrm{~g})$. In the case of $R$. rosifolius, the vitamin C contents obtained during the ripening stage $\mathrm{I}$ and ripening stage II were lower than the vitamin $\mathrm{C}$ contents at ripe fruit (54.30 $\mathrm{mg} / 100 \mathrm{~g}$ ). Rahman et al. [25] reported that the amount of ascorbic acid in plants varies greatly, depending on such factors like the variety, weather, and maturity. In our experiment, fruits were harvested from the different plant at the same time. Furthermore, the ascorbic acid

Table 2. Nutrients analysis of five species of wild raspberries (Rubus spp.)

\begin{tabular}{lccccc}
\hline \multicolumn{1}{c}{ Species } & Fruit Colour & $\begin{array}{c}\text { Total Carbohydrate } \\
(\%)\end{array}$ & $\begin{array}{c}\text { Sugar } \\
\text { (gram) }\end{array}$ & $\begin{array}{c}\text { Raw Fiber } \\
\text { (\%) }\end{array}$ & $\begin{array}{c}\text { Calorie } \\
\text { (Cal.) }\end{array}$ \\
\hline Rubus fraxinifolius & Red & 11.48 & 5.05 & 6.43 & 45.92 \\
Rubus rosifolius & Red & 9.86 & 2.76 & 7.10 & 39.44 \\
Rubus pyrifolius & Dark Red & 6.84 & 3.48 & 3.36 & 27.54 \\
Rubus chrysophyllus & Yellow & 11.15 & 2.73 & 8.43 & 44.62 \\
Rubus lineatus & Orange & 9.50 & 3.11 & 6.39 & 38.00 \\
Raspberry & Red & 11.94 & 4.42 & 6.50 & 52.00 \\
\hline
\end{tabular}

*) Data from USDA 2014 [24] 


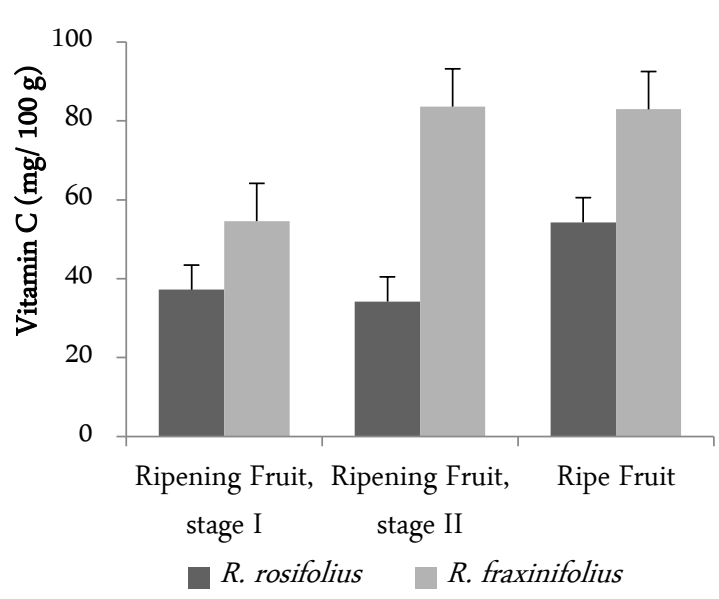

Figure 2. Comparison of vitamin $\mathrm{C}$ content to three levels of fruit maturities

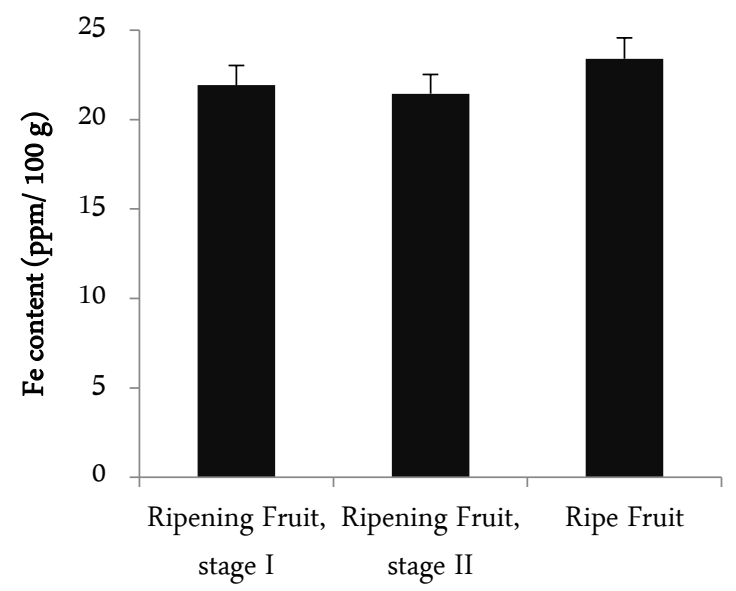

Figure 3. Comparison of iron/Fe content to three levels of $R$. fraxinifolius fruits

content of fruits is never constant but varies with some plant at the same time. Furthermore, the ascorbic acid content of fruits is never constant but varies with some factors which include climatic/environmental conditions, maturity state, and position on the tree, handling and storage, ripening stage, species and variety of the fruits as well as temperature [26]. However, the ascorbic acid content of the selected unripe fruits was found to be greater than that of the ripe ones. Also, the ascorbic acid decreased upon ripening, temperature increase and time which are attributed to degradation caused by heat and oxidation [27]. It has been reported that high nitrogen fertilizer rates can decrease ascorbic acid levels in fruits and that proper potassium levels are needed for good ascorbic acid levels. Additionally, climate, especially temperature-total available heat affects ascorbic acid levels. Areas with cool nights produce fruits with higher ascorbic acid levels while hot tropical areas pro- duce citrus fruit with lower levels of ascorbic acid. Environmental conditions that increase the acidity of citrus fruits also increase ascorbic acid levels. The position of citrus fruits on the tree also affects ascorbic acid levels. All these and more contributed to the reasons behind the erratic values of ascorbic acid contents of citrus fruits all over the world [28].

Iron $(\mathrm{Fe})$ is a mineral micronutrient considered essential in human nutrition besides manganese $(\mathrm{Mn})$, copper $(\mathrm{Cu})$, zinc $(\mathrm{Zn})$, cobalt $(\mathrm{Co})$, sodium $(\mathrm{Na})$, chlorine $(\mathrm{Cl})$, iodine $(\mathrm{I})$, fluorine $(\mathrm{F})$, sulfur $(\mathrm{S})$, and selenium (Se). Iron, a redox active metal, plays an important role in the oxidative defense system. In general, vegetables are a richer source of minerals than fruits, but both vegetables and fruits are considered "nutrient-dense foods" in that they provide substantial amounts of micronutrients, such as minerals and vitamins, but relatively few calories [29]. By comparing three level of maturity fruits of $R$. fraxinifolius, the results show that iron content in ripe fruit is higher than ripening fruit stage I and ripening fruit stage II (Figure 3). Our results were in line with Wegwu and Amadi [30] that reported iron contents of ripe fruits is higher than unripe fruits. Moreover, Ahmad et al. [23] reported that iron content of wild Rubus varied between $2.16 \mathrm{mg} / 100 \mathrm{~g}$ to 4.25 $\mathrm{mg} / 100 \mathrm{~g}$. Referring to USDA Data for raspberries, the iron content of $R$. fraxinifolius is very low. The USDA data show that iron content or raspberries were $0.7 \mathrm{mg} / \mathrm{g}$ [24]. The essentiality of iron residues in its capacity to participate in one-electron exchange reactions. Iron is required in numerous essential proteins, such as the heme-containing proteins, electron transport chain and microsomal electron transport proteins, and iron-sulfur proteins and enzymes such as ribonucleotide reductase, prolyl hydroxylase phenylalanine hydroxylase, tyrosine hydroxylase and aconitase [31]. Iron is a constituent of the haem complex, a naturally occurring plant chelate involved in electron transfer in a number of important plant enzymes [32].

Fruit quality and nutrient are a premier factor to be considered in order to develop new cultivar and improved wild raspberries. Although many other characteristics such as agronomic performance, the primary objectives in modern raspberry breeding focus on highquality fruit, good yield, shelf life and suitability for shipping for the fresh market and for mechanical harvesting for processing [33].

\section{CONCLUSION}

This research demonstrated that the total carbohy- 
drate, sugar, raw fiber and calorie varied among five species of wild raspberries from Indonesian mountain's forests. In the other hand, the maturity of the fruit which is the stage of ripening and ripe fruit affected the value of vitamin $\mathrm{C}$ and iron on $R$. fraxinifolius and $R$. rosifolius fruits. It can be considered as a period for harvesting in order to obtain an ideal consumption quality of fruit.

\section{ACKNOWLEDGMENT}

The authors are thankful for financial assistance provided by Indonesian Institute of Sciences through "DIPA Tematik UPT BKT Kebun Raya Cibodas", to conduct project on "Domestikasi Rubus spp. asal Indonesia sebagai tanaman buah".

\section{REFERENCES}

1. Hopkins J, Maxted N (2011) Crops wild relatives: Plant conservation for food security. Birmingham, Natural England and the University of Birmingham.

2. Alice LA, Campbell CS (1999) Phylogeny of Rubus (Rosaceae) based on nuclear ribosomal dna internal transcrobeff spacer region sequences. American Journal of Botany 86 (1): 81 - 97. doi: 10.2307/2656957.

3. Hummer KE (2010) Rubus pharmacology: Antiquity to the present. HortScience 45 (11): 1587 - 1591.

4. Backer CA, van de Brink RCB. (1963) Flora of Java (Spermatophyte only) vol. I. N.V.P. Springer, Noordhof - Groningen.

5. van Steenis CGGJ (1972) The Mountain flora of Java. E. J. Brill, Leiden.

6. Kalkman C (1993) Rosaceae. In Flora Malesiana ser. I. Vol. 11 van Steenis CGGJ, van Steenis-Kruseman MJ, Departemen Pertanian Indonesia, Lembaga Ilmu Pengetahuan Indonesia, Kebun Raya Indonesia Eds. Jakarta, Noordhoff Kolff. pp $227-351$.

7. Surya MI (2009) Keanekaragaman dan potensi Rubus spp. koleksi Kebun Raya Cibodas. Warta Kebun Raya 9 (1): 21 26.

8. Surya MI, Ismaini L, Destri (2015) Keragaman buah raspberries (Rubus spp.) asal Indonesia. Prosiding Seminar Nasional Biologi: 296 - 305.

9. Normasiwi S, Surya MI. (2016) The potential plant for fruit crop in Cibodas Botanical Garden. Biosantifika: Journal of Biology and Biology Education 8 (2): 206 - 213.

10. Thompson MM (1995) Chromosome numbers of Rubus species at the National Clonal Germplasm Repository. Hort Science 30 (7): 1447 - 1452.

11. Hummer KE (1996) Rubus diversity. Hort Science 31 (2): $182-183$.

12. Howarth DG, Gardner DE, Morden CW (1997) Phylogeny of Rubus subgenus Idaeobatus (Rosaceae) and its implications toward colonization of the Hawaiian Islands. Systematic Botany 22 (3): 433 - 441. doi: 10.2307/2419819.

13. Harrison RE, McNicol RJ, Jennings S (1997) Soft fruit and perennial crops: Rubus breeding and genetic research. Scottish crop research institute Ann. Rep. 1996/1997: 63 - 68.

14. Knight VH (2004) Rubus breeding worldwide and the raspberry breeding programme at horticultural research international, east mailing. Jugoslovensko Vocarstvo 38: 145 - 146.

15. Kaume L, Howard LR, Devareddy L (2011) The blackberry fruit: a review on its composition and chemistry, metabolism and bioavailability, and health benefits. Journal of Agricultural and Food Chemistry 60 (23): 5716 - 5727. doi: 10.1021/jf203318p.

16. Talcott ST (2007) Chemical components of berry fruits. In: Zhao Y eds. Berry fruit value added products for health promotion. Florida, CRC Press. pp $51-72$.

17. van Valkenburg JLCH, Bunyapraphatsara N (2002) Medicinal and poisonous plants 2. Plant resouces of South-East Asia No. 12 (2). Oegstgeest, Backhuys Publishers.

18. Pearson D (1976) The chemical analysis of foods. London, Churchill Livingstone.

19. Probst $Y$ (2015) A review of the nutrient composition of selected Rubus berries. Nutrition and Food Science 45 (2): 242 - 254. doi: 10.1108/NFS-07-2014-0063

20. Smith MM, Davis M, Chasalow FI, Lifshitz F (1995) Carbohydrate absorption from fruit juices in young children. Pediatrics. 95 (3): $340-344$.

21. Serpen JY (2012) Comparison of sugar content in bottled $100 \%$ fruit juice versus extracted juice of fresh fruit. Food and Nutrition Sciences 3 (11): 1509 - 1513. doi: 10.4236/fns.2012.311196.

22. Trowell H (1976) Definition of dietary fiber and hypotheses that it is a protective factor in certain diseases. The American Journal of Clinical Nutrition 29 (4): 417 - 427.

23. Ahmad M, Masood S, Sultana S et al. (2015) Report: Antioxidant and nutraceutical value of wild medicinal Rubus berries. Pakistan Journal of Pharmaceutical Sciences 28 (1): 241 $-247$.

24. USDA (2014) National nutrient database for standard reference release 28. http://ndb.nal.usda.gov/. Accessed: February 7, 2016.

25. Rahman MM, Khan MMR, Husain MM (2007) Analysis of vitamin C (ascorbic acid) Contents in various fruits and vegetables by UV spectroscopy. Bangladesh Journal of Scientific and Industrial Research 42 (4): 417 - 424. doi: 10.3329/bjsir.v42i4.749.

26. Luisa JB, Laura AM, Consuelo DM (2014) Evaluation of the antioxidant properties and aromatic profile during maturation of the blackberry (Rubus glaucus Benth) and the bilbe- 
rry (Vaccinium meridionale Swartz). Revista Facultad Nacional de Agronomía, Medellín 67 (1): 7209 - 7218. doi: 10.15446/rfnam.v67n1.42649.

27. Muhammad I, Ashiru S, Ibrahim DI et al. (2014) Effect of ripening stage on vitamin $\mathrm{C}$ content in selected fruits. International Journal of Agriculture, Forestry and Fisheries 2 (3): $60-65$.

28. Igwe OU (2014) Quantitative estimation of a scorbic acid levels in citrus fruits at variable temperatures and physicochemical properties. International Journal of Chemical and Biochemical Science 5: $67-71$.

29. Vicente AR, Manganaris GA, Sozzi GO, Crisosto $\mathrm{CH}$. (2009) Postharvest handling: A systems approach, 2nd ed. In: Florkowski WJ, Shewfelt RL, Brueckner B, Prussia SE eds. Nutritional quality of fruits and vegetables. Amsterdam, Elsevier Inc.

30. Wegwu MO, Amadi FA (2007) Comparison of mineral content of some ripe and unripe fruits in Nigeria. Plant Products Reserach Journal 11 (1): 15 - 18. doi: 10.4314/pprj.v11i1.352 60.

31. Arredondo M, Núñez MT (2005) Iron and copper metabolism. Molecular Aspects of Medicine 26 (4 - 5): 313 - 327. doi: 10.1016/j.mam.2005.07.010.

32. Mengel K, Kirkby EA (1982) Principles of plant nutrition. Worblaufen-Bern, International Potash Institute.

33. Brennan R, Graham J (2009) Improving fruit quality in Rubus and Ribes through breeding. Functional Plant Science and Biotechnology 3 (Special Issue 1): $22-29$. 